\title{
Antiproliferative and apoptosis induction of $\alpha$-mangostin in T47D breast cancer cells
}

\author{
SOMCHAI KRITSANAWONG $^{1}$, SUKANDA INNAJAK ${ }^{1}$, MASAYA IMOTO $^{2}$ and RAMIDA WATANAPOKASIN ${ }^{1}$ \\ ${ }^{1}$ Department of Biochemistry, Faculty of Medicine, Srinakharinwirot University, Bangkok 10110, Thailand; \\ ${ }^{2}$ Department of Bioscience and Information, Faculty of Science and Technology, Keio University, Yokohama, Japan
}

Received November 5, 2015; Accepted February 8, 2016

DOI: $10.3892 /$ ijo.2016.3399

\begin{abstract}
Mangostin extracted from mangosteen, Garcinia mangostana Linn. is known as 'queen of fruits'. The anticancer activity of $\alpha$-mangostin through apoptosis induction and related signaling pathways in human breast cancer T47D cells was investigated. Human epidermal growth factor receptor 2 (HER2) and mitogen-activated protein kinase (MAPK) signaling have been shown to play important roles in apoptosis. The results showed that $\alpha$-mangostin induced cell proliferation inhibition, DNA fragmentation, nuclear condensation, increased cleaved caspase-3 and cleaved caspase-9, but decreased Bcl-2 and Mcl-1 expression. Mitochondrial dysfunction and cytochrome $c$ release were also detected. In addition, phosphorylation of ER $\alpha$, HER2, PI3K, Akt and ERK1/2 were downregulated whereas p-JNK1/2 and p-p38 were upregulated. These results indicated that $\alpha$-mangostin induced apoptosis associated with HER2/PI3K/Akt and MAPK signaling pathways suggesting that $\alpha$-mangostin may be used as food supplement or a potential therapeutic compound for breast cancer.
\end{abstract}

\section{Introduction}

Breast cancer is the most common type of cancer in women and is the second leading cause of cancer death following lung cancer, resulting from coordinated actions between estrogen receptor (ER) and growth factor receptor especially for HER2 and various survival signaling pathways (1). Increasing efforts are conducted on identifying not only agents that selectively target cancer cells but also signaling pathways that promote or inhibit cancer progression. Targeting a specific pathway is critical to successful treatment of breast cancer, as cancer cells reflect the balance between cell death and survival (2). ERs are

Correspondence to: Professor Ramida Watanapokasin, Department of Biochemistry, Faculty of Medicine, Srinakharinwirot University, Bangkok 10110, Thailand

E-mail: ramidawa@yahoo.com

Key words: $\alpha$-mangostin, breast cancer, apoptosis, PI3K, Akt, MAPK a group of nuclear receptor (NR) transcription factors, which could be activated by estrogen hormone. There are two classical nuclear ER subtypes, ER $\alpha$ and ER $\beta$. Approximately $70 \%$ of breast cancer cases are ER-positive (3). Signaling of ER $\alpha$ is involved in normal breast development, as well as in growth and progression of breast cancer. HER2, an orphan receptor with intrinsic tyrosine kinase activity, regulates cell growth, differentiation and survival $(4,5)$. Excess HER2 signaling leads to numerous oncogenic processes including cell proliferation, survival and carcinogenesis (6) via the RAS/Raf1/MEK/ERK and the PI3K/Akt pathways. Moreover, crosstalk between ER $\alpha$ and HER2 signaling pathways fundamentally contribute to the development and aggressiveness of cancer (7).

Apoptosis is a form of programmed cell death which is precisely regulated and plays important roles during embryogenesis and immunology (8-11). Apoptosis is characterized by a number of well-defined features including cellular morphological changes, chromatin condensation, DNA fragmentation and caspase activation. Apoptosis (program cell death) proceeds through two main pathways, the extrinsic and intrinsic pathways. The extrinsic pathway is triggered through the binding of death ligands such as tumor necrosis factor- $\alpha$ (TNF- $\alpha$ ), cluster of differentiation 95 ligand (CD95L)/Fas ligand (FasL) or TNF-related apoptosis-inducing ligand (TRAIL) to death receptors on the cell surface resulting in formation of death-inducing signaling complexes (DISC) and activation of initiator caspases-8 (12). On the contrary, the intrinsic or mitochondrial pathway is initiated by cellular or DNA damage characterized by depolarization of mitochondrial membrane e controlled by the Bcl-2 family proteins leading to cytochrome $c$ release into cytoplasm and caspase-9 activation (13). Both pathways promote cleaved caspase-3 expression then PARP degradation, DNA fragmentation and apoptotic cell death. Apoptosis is regulated by a variety of signaling pathways including the PI3K/Akt pathway. Protein kinase $\mathrm{B}(\mathrm{Akt})$ has been shown to regulate apoptosis related proteins such as B cell lymphoma-2 (Bcl-2), Bcl-2 associated $\mathrm{X}$ protein (Bax) and cysteine aspartic acid specific protease (caspase-3) and is crucially involved in anticancer drug induced apoptosis of cancer cells (14-17).

MAPK signaling, targeted for cancer prevention and treatment, includes a three-tiered kinase core, where MAP3K activates MAP2K that activates MAPKs including ERK1/2 which promotes cell growth, cell survival and differentia- 
tion whereas JNK1/2 and p38 promote cell apoptosis $(18,19)$. Moreover, $\alpha$-mangostin also showed decreased inactiveMAPK(s) by dephosphorylation of c-Raf at Ser259. Therefore, downregulation of phosphorylated-ERK1/2 may be an appropriate alternative therapy for breast cancer patients (20).

Various signaling pathways were activated upon the binding of estrogen to ER $\alpha$ including Ras-Raf-MAP kinase and PI3K/Akt signaling pathways (21). ER $\alpha$ phosphorylation is involved in tamoxifen resistance including Ser104/106 and Ser118 in breast cancer patients (22). These regions of ER $\alpha$ were phosphorylated by ERK1/2 and MEK1/2 $(23,24)$. ERK/MAPK and PI3K/Akt pathways rapidly activated by the ER $\alpha$-estrogen complex also have a critical role in estrogen action as a survival agent. Furthermore, p38 phosphorylated-ER $\alpha$ (at Ser294) in coordination with S-phase kinase-associated protein 2 (Skp2) which stimulated phosphorylation of ER $\alpha$ at Ser64 led to proteosomal degradation of ER $\alpha$. In addition, inhibition of p38 and Skp2 affected the ER $\alpha$ function (25). Indeed, these pathways enhanced $\mathrm{Bcl}-2$ expression, blocked p38 activation and reduced caspase-3 activation $(26,27)$.

Mangosteen (Garcinia mangostana Linn.) family Guttiferae has been used for hundreds of years around the world, mainly in Southeast Asia. Mangosteen is round, dark purple or reddish fruit with white juicy pulp possessing slightly acidic and sweet flavor, known as the 'queen of fruits' (28). The juicy pulp contains essential nutrients such as carbohydrates, fat, protein, vitamins and trace metals. The fruit hulls were used as a traditional herbal medicine for the treatment of abdominal pain, dysentery, wound infections, eczema, suppuration and chronic ulcer (29-31). Xanthones, the most abundant polyphenolic compounds present in mangosteen pericarp, have long been reported to possess multiple health-promoting properties (32). The dominant xanthone extracted from the fruit hulls of $G$. mangostana, $\alpha$-mangostin, has been demonstrated to possess antioxidant (33-35), antibacterial $(36,37)$, antifungal (38), anti-inflammatory $(39,40)$, renoprotective activities (41). Effects of $\alpha$-mangostin have been reported in numerous preclinical tumor models such as colon cancer (42), colorectal (43), leukemia (44), chondrosarcoma (45).

In the present study, we investigated the hypothesis that $\alpha$-mangostin could inhibit cell proliferation and induce apoptosis associated with HER2/PI3K/Akt and MAPK signaling pathway in human breast carcinoma T47D cells.

\section{Materials and methods}

Chemical. Hoechst 33342, fetal bovine serum (FBS), crystal violet, 3-(4,5-dimethylthiazol-2-yl)-2,5-diphenyltetrazolium bromide (MTT), phenylmethylsulphonylfluoride (PMSF), 2-(4-(2-hydroxyethyl)-1-piperazinyl)-ethanesulphonic acid (HEPES), ethylenediaminetetraacetic acid (EDTA), Ethylene glycol-bis (2-aminoethylether)-N,N,N',N'-tetraacetic acid (EGTA) and phenol:chloroform:isoamyl alcohol (25:24:1) were purchased from Sigma-Aldrich (St. Louis, MO, USA). Dulbecco's modified Eagle's medium (DMEM) and Roswell Park Memorial Institute (RPMI)-1640 medium were purchased from Gibco (Grand Island, NY, USA). Propidium iodide (PI), Hoechst 33342 (2,5'-Bi-1H-benzimidazole, 2'-(4-ethoxyphenyl)-5-(4-methyl-1-piperazinyl)-23491-52-3), JC-1 (5,5',6,6'-tetrachloro-1,1',3,3'-tetraethyl-imidacarbo- cyanine iodide) and DNase free RNase A were purchased from Thermo Fisher Scientific Inc. (Pittsburgh, PA, USA). Dimethylsulfoxide (DMSO) was purchased from Merck Calbiochem (San Diego, CA, USA). $\alpha$-Mangostin was isolated and purified by A. Krajarng according to our previous report (45). The structure of $G$. mangostana is shown in Fig. 1A (46).

Cell culture. Breast cancer cell lines MDA-MB-468, AU565, SKBR3 and T47D were obtained from the American Type Culture Collection (ATCC; Manassas, VA, USA). MDA-MB-468 was maintained as a monolayer in DMEM. AU565, SKBR3 and T47D were maintained as a monolayer in RPMI-1640. The media were supplemented with $10 \%$ fetal bovine serum (FBS) $100 \mathrm{U} / \mathrm{ml}$ penicillin, $100 \mu \mathrm{g} / \mathrm{ml}$ streptomycin (PAA Laboratories, Pasching, Austria). Cells were cultured in $5 \% \mathrm{CO}_{2}$ at $37^{\circ} \mathrm{C}$. The medium was refreshed every 2-3 days.

Evaluation of proliferation inhibitory potential (MTT assay). The cytotoxicity of $\alpha$-mangostin was determined by MTT assay. MDA-MB-468, AU565, SKBR3 and T47D cells were seeded at a density of $1 \times 10^{4}$ cells/well in a 96-well plate and allowed to grow for $24 \mathrm{~h}$. Cells were then treated with $\alpha$-mangostin at $7.5,15$ and $30 \mu \mathrm{M}$, whereas the control group was treated with $0.03 \%$ DMSO. After incubation for 4,8 , 12, 16, 20 and $24 \mathrm{~h}$, MTT solution $(0.5 \mathrm{mg} / \mathrm{ml})$ was added to each well and was further incubated for $3 \mathrm{~h}$ at $37^{\circ} \mathrm{C}$. DMSO was added to each well to solubilize water insoluble purple formazan crystals. The absorbance at $570 \mathrm{~nm}$ was measured using a microplate reader (Multiskan EX; Thermo Electron Corp., Vantaa, Finland). Survival percentage (\%) was calculated relative to the control.

The $\mathrm{IC}_{50}$ of $\mathrm{T} 47 \mathrm{D}$ cells was $7.5 \mu \mathrm{M}$, which was less than Vero cells $(14.26 \mu \mathrm{M})$, whereas those of SKBR3, MDA-MB-468 and AU565 were 23.88, 22.23 and $43.63 \mu \mathrm{M}$, respectively. Thus, T47D cells were chosen for further study. The reason for choosing different times depended on which step of apoptosis occurs at each period, as each protein will be expressed at different times. The survival proteins were reduced with increasing of time.

Colony formation assay. T47D cell suspensions were seeded at a density of $4 \times 10^{4}$ cells/well in a $35-\mathrm{mm}$ tissue culture dish and allowed to grow for $24 \mathrm{~h}$ at $37^{\circ} \mathrm{C}$. Cells were treated with 15 and $30 \mu \mathrm{M} \alpha$-mangostin for 3 and $6 \mathrm{~h}$. After 14 days colonies were fixed with $100 \%$ methanol and stained with $2 \%$ (w/v) crystal violet (Suvchem Laboratory Chemicals, Mumbai, India). The number of colonies $\geq 50$ cells was counted and colony formation efficiency was calculated.

Nuclear morphology staining with Hoechst 33342. T47D cells were seeded at a density of $5 \times 10^{4}$ cells/dish for $24 \mathrm{~h}$ then treated with $30 \mu \mathrm{M} \alpha$-mangostin for $3,6,9$ and $12 \mathrm{~h}$ at $37^{\circ} \mathrm{C}$. The cells were then stained with $10 \mu \mathrm{M}$ Hoechst 33342 and examined under fluorescence microscope (IX73; Olympus, Tokyo, Japan).

DNA fragmentation analysis. T47D cells at $2 \times 10^{6}$ cells/well were seeded in 60-mm tissue culture dish and treated with 0 , 
15 and $30 \mu \mathrm{M} \alpha$-mangostin for $24 \mathrm{~h}$. For DNA fragmentation assay, low molecular weight DNA was isolated (47). Briefly, T47D cells treated with $\alpha$-mangostin were collected, washed and resuspended in TE $(10 \mathrm{mM}$ Tris- $\mathrm{HCl}, \mathrm{pH} 8.0$ and $1 \mathrm{mM}$ EDTA) buffer. Then lysis buffer (5 mM Tris- $\mathrm{HCl}$, pH 8.0 and $20 \mathrm{mM}$ EDTA and $0.5 \%(\mathrm{v} / \mathrm{v})$ Triton X-100) was added, resuspended and kept at $-20^{\circ} \mathrm{C}$ overnight. The mixture was centrifuged at $14,000 \times \mathrm{g}$ for $15 \mathrm{~min}$. The supernatant was then collected and extracted with phenol:chloroform:isoamyl alcohol $(25: 24: 1)$ followed by butanol and precipitated with absolute ethanol. The pellet was dried and dissolved in TE buffer, incubated with $100 \mu \mathrm{g} / \mathrm{ml}$ DNase free RNase A for $2 \mathrm{~h}$ at $37^{\circ} \mathrm{C}$ and incubated with $200 \mu \mathrm{g} / \mathrm{ml}$ proteinase $\mathrm{K}$ (Vivantis Inc., Oceanside, CA, USA) at $60^{\circ} \mathrm{C}$. The sample DNA was analyzed using $1.8 \%$ agarose gel (Vivantis) and visualized by ethidium bromide staining.

Cell cycle analysis. T47D cells were seeded at $6 \times 10^{5}$ cells/well in a 6-well plate then treated with 0,15 and $30 \mu \mathrm{M} \alpha$-mangostin for $12 \mathrm{~h}$, washed with ice cold PBS, fixed with $70 \%$ ethanol and stored at $-20^{\circ} \mathrm{C}$ then resuspended in DNA staining solution (50 $\mu \mathrm{g} / \mathrm{ml}$ propidium iodide, $200 \mu \mathrm{g} / \mathrm{ml}$ DNase free RNase A, $0.1 \%$ Triton $\mathrm{X}-100,0.1 \%$ sodium citrate). Cells were washed and incubated at $4^{\circ} \mathrm{C}$ overnight in the dark and analyzed for DNA content on a BD Accuri C6 flow cytometer (Accuri Cytometers, Inc., Ann Arbor, MI, USA) at $488 \mathrm{~nm}$ excitation. The forward scatter and red fluorescence above $600 \mathrm{~nm}$ were measured.

Measurement of mitochondrial membrane potential $(\Delta \Psi m)$. The changes in mitochondrial membrane potential $(\Delta \Psi \mathrm{m})$ were determined using JC-1, a lipophilic fluorescent cation that incorporates into the mitochondrial membrane. Intact living cells stained with JC-1 exhibits pronounced red fluorescence, whereas break-down of the mitochondrial membrane potential in apoptotic cells shows decreased red fluorescence and reveals green fluorescence. Cells were treated with $30 \mu \mathrm{M} \alpha$-mangostin and the control cells were treated with $0.03 \%$ DMSO, and then were stained with $10 \mu \mathrm{g} / \mathrm{ml} \mathrm{JC}-1$.

Detection of cytochrome c release. Upon treatment of T47D cells in the absence or presence of $30 \mu \mathrm{M} \alpha$-mangostin, cells were resuspended in $\mathrm{S}-100$ lysis buffer $(20 \mathrm{mM}$ HEPES, pH 7.5, $10 \mathrm{mM} \mathrm{KCl}, 1.5 \mathrm{mM} \mathrm{MgCl}_{2}, 1 \mathrm{mM}$ EGTA, $1 \mathrm{mM}$ EDTA and $250 \mathrm{mM}$ sucrose) and homogenized for 30-40 strokes. Cell were centrifuged at $500 \mathrm{x} \mathrm{g}$ for $5 \mathrm{~min}$ at $4^{\circ} \mathrm{C}$ (to eliminate nuclei and unbroken cells). The supernatant was taken to a new tube, then centrifuged at $10,000 \mathrm{x} \mathrm{g}$ for $30 \mathrm{~min}$ at $4^{\circ} \mathrm{C}$. Pellet contained mitochondria and supernatant contained cytosolic fraction. The protein was separated by $12 \%$ sodium dodecyl sulphate polyacrylamide gel electrophoresis (SDS-PAGE), transferred onto polyvinylidene fluoride (PVDF) membranes (GE Healthcare, Buckinghamshire, UK) and subjected to immunodetection of cytochrome $c$ using a rabbit polyclonal antibody against human cytochrome $c$ (Cell Signaling Technology, Beverly, MA, USA). The peroxidase activity of bound secondary antibodies on the blots was detected by enhanced chemiluminescence reagent (ECL; GE Healthcare) and detected under chemiluminescent imaging system (GeneGnome gel documentation; Synoptics Ltd., Cambridge, UK).

Western blot analysis. T47D cells were seeded at $6 \times 10^{5}$ cells/well in a $35-\mathrm{mm}$ culture dish, exposed with $30 \mu \mathrm{M}$ $\alpha$-mangostin and harvested at designated time-points. Cells were lysed with RIPA (radioimmunoprecipitation assay) buffer (50 mM Tris-HCl, pH 7.5, 5 mM EDTA, $250 \mathrm{mM} \mathrm{NaCl}, 0.5 \%$ Triton X-100) supplemented with complete mini-protease inhibitor cocktail (Roche Diagnostics GmbH, Mannheim, Germany). The protein content was determined using Bio-Rad protein assay kit (Bio-Rad Laboratories, Hercules, CA, USA), separated by 10-12\% SDS-PAGE and transferred onto PVDF membrane using a Mini Trans-Blot Cell ${ }^{\circledR}$ (Bio-Rad Laboratories). The blots were incubated overnight at $4^{\circ} \mathrm{C}$ with appropriate primary antibodies (Cell Signaling Technology). The membranes were washed and incubated with appropriate secondary antibodies conjugated with horseradish peroxidase (Cell Signaling Technology) for $1 \mathrm{~h}$ at room temperature. Immunoreactive protein bands were detected by chemiluminescence using ECL.

Statistical analysis. All data presented were obtained from at least three independent experiments and are presented as mean \pm standard deviation (SD). Statistical significance was assessed by one-way analysis of variance (ANOVA). Statistical analysis was performed using the SPSS statistical software package (version 11.5) as well as GraphPad Prism 3.03 (GraphPad Software, Inc., San Diego, CA, USA). The protein band intensity was quantified by ImageJ densitometer. Asterisks in the figures indicate that the experimental values are significantly different from those of the control $\left({ }^{*} \mathrm{P}<0.05\right.$, $\left.{ }^{* *} \mathrm{P}<0.01\right)$.

\section{Results}

$\alpha$-Mangostin decreases cell viability in T47D human breast cancer cells. The effect of $\alpha$-mangostin on cell viability in T47D cells treated with $\alpha$-mangostin at various concentrations and times was determined and the results showed that the $\mathrm{IC}_{50}$ value was $7.5 \pm 0.5 \mu \mathrm{M}$ at $24 \mathrm{~h}$ (Fig. $1 \mathrm{~A}$ ), and cell viability was dose- and time-dependent comparing to the control cells.

$\alpha$-Mangostin inhibits colony formation and proliferation of breast cancer cells. The results indicated that $\alpha$-mangostin inhibited colony formation in T47D cells in a time- and dosedependent manner (Fig. 1B). T47D cells treated with $30 \mu \mathrm{M}$ $\alpha$-mangostin for $6 \mathrm{~h}$ grew slightly, but less than at $15 \mu \mathrm{M}$ $\alpha$-mangostin. The quantitative data of colony formation assay were calculated and compared with untreated control cells in three independent experiments (Fig. 1C and D).

Morphological and nuclei changes. Treatment of T47D cells with $30 \mu \mathrm{M} \alpha$-mangostin for 3, 6, 9 and $12 \mathrm{~h}$ showed evident morphological changes including vacuolization, cell shrinkage and rounding (Fig. 2A). The result also showed chromatin condensation, a characteristic of apoptotic cells (Fig. 2B).

Cell cycle distribution and chromosomal DNA fragmentation. DNA fragmentation, a ladder-like pattern, typical DNA 
A<smiles>C=COc1cc2oc3cc(O)c(O)c(CC=C(C)C)c3c(=O)c2c(O)c1CC=C(C)C</smiles>

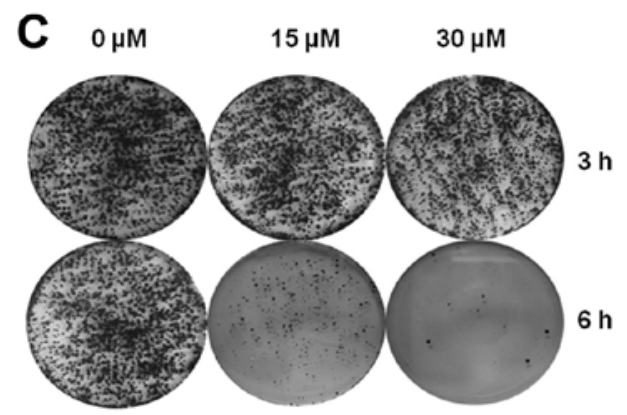

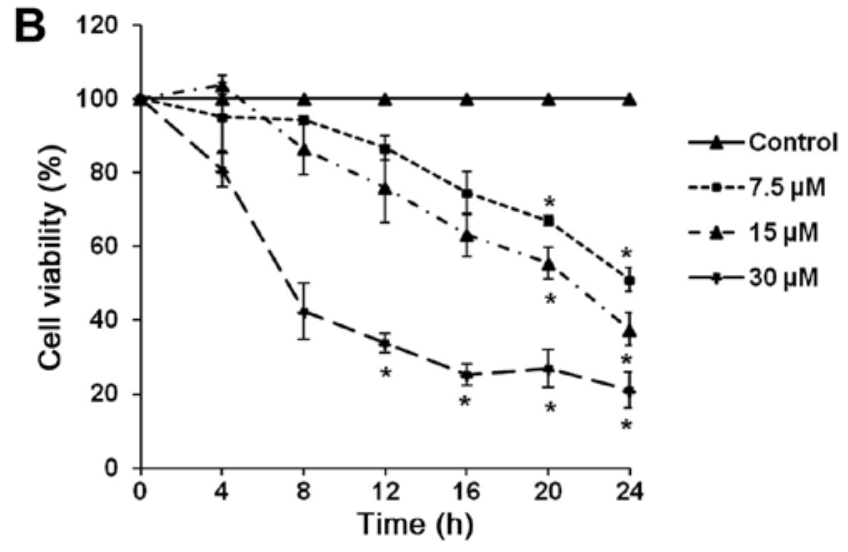

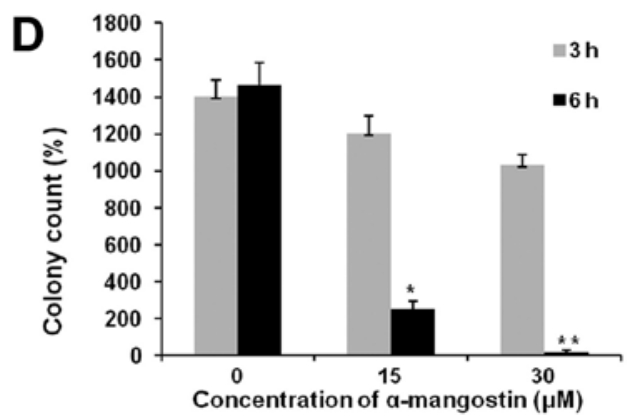

Figure 1. Effects of $\alpha$-mangostin on cell viability and colony formation in T47D cells. (A) Structure of $\alpha$-mangostin isolated from $G$. mangostana fruit hull. (B) Time- and dose-dependent effect of $\alpha$-mangostin on T47D cells treated with different concentrations of $\alpha$-mangostin at various time-points. Results are mean values \pm SD of three independent experiments performed in triplicate $(n=3)$. (C) Representative dishes of colony formation assay. (D) The quantitative data of colony formation assay are presented as the mean $\pm \mathrm{SD}$ of relative increase as compared to the untreated control cells in three independent experiments. Significant values were defined as ${ }^{*} \mathrm{P}<0.05$ and ${ }^{* *} \mathrm{P}<0.01$ as compared to the control.
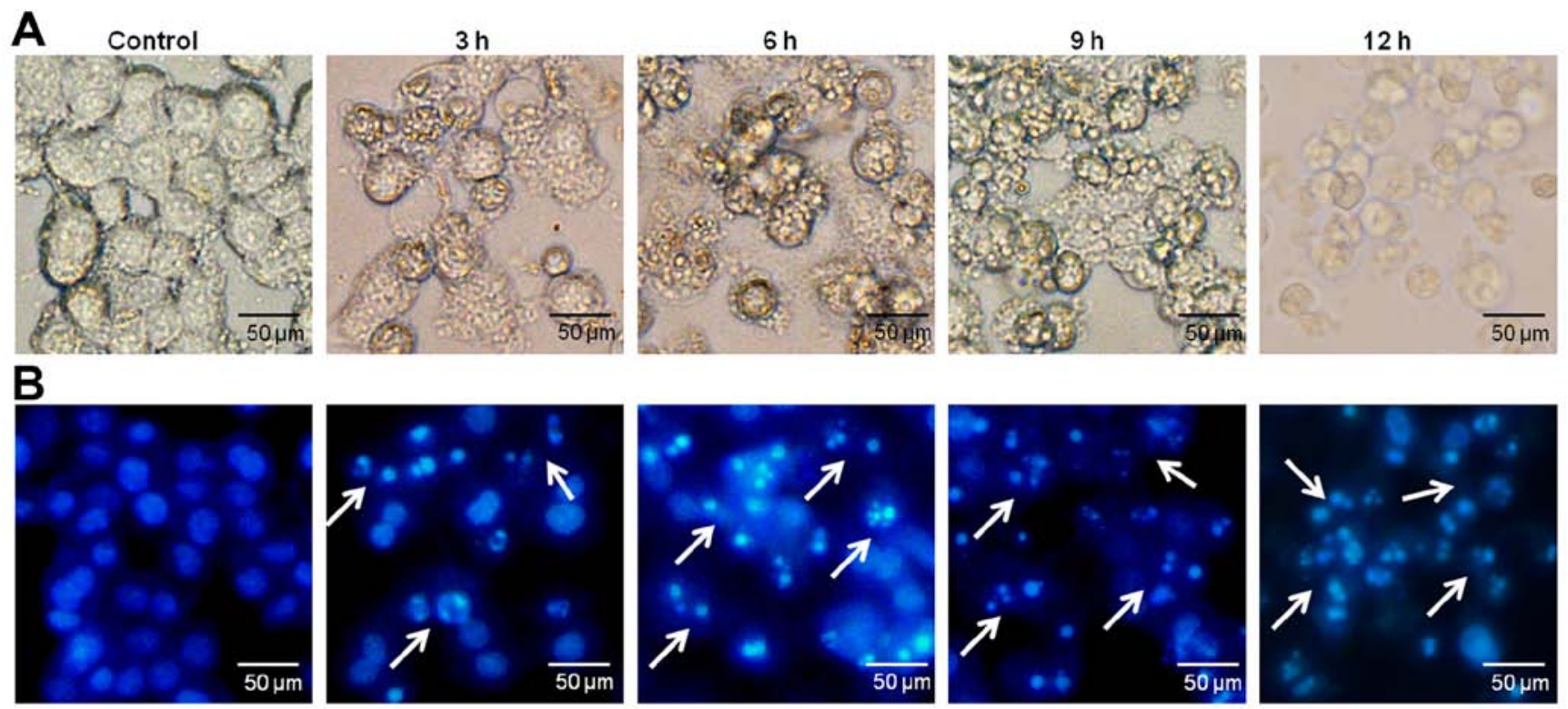

Figure 2. Effects of $\alpha$-mangostin on cell morphology and nuclear condensation of T47D cells. (A) Morphological changes of control cells (0.03\% DMSO), $30 \mu \mathrm{M} \alpha$-mangostin for 3, 6,9 and $12 \mathrm{~h}$. (B) T47D cells stained with Hoechst 33342 and examined under a fluorescent microscope (magnification, $\mathrm{x} 40$ ).

cleavage between nucleosome was visible dose-dependently after incubation with $\alpha$-mangostin, whereas, not in the control (Fig. 3A). The effect of $\alpha$-mangostin on cell cycle distribution showing two major peaks represented the G0/G1 and G2/M phases, the sub G1 peak with reduced DNA content represented apoptotic cells. The mean apoptotic population of T47D cells was $3.3 \%$ under the control condition as compared to 12.6 and $21.0 \%$ upon treatment with 15 and $30 \mu \mathrm{M} \alpha$-mangostin for $12 \mathrm{~h}$, respectively (Fig. 3B and C).

Effects of $\alpha$-mangostin on the mitochondrial membrane potential $(\Delta \Psi m)$. Bax oligomers increased mitochondrial 


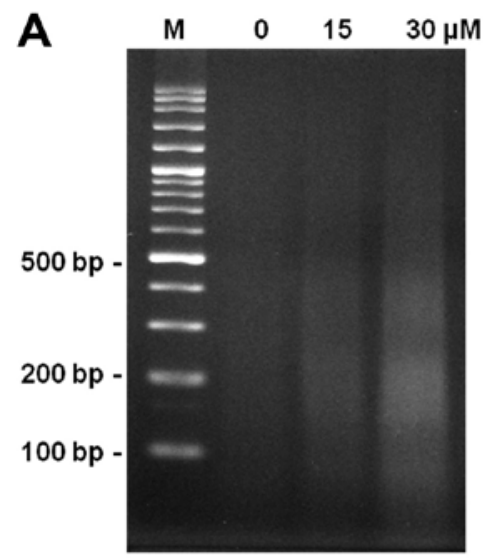

B

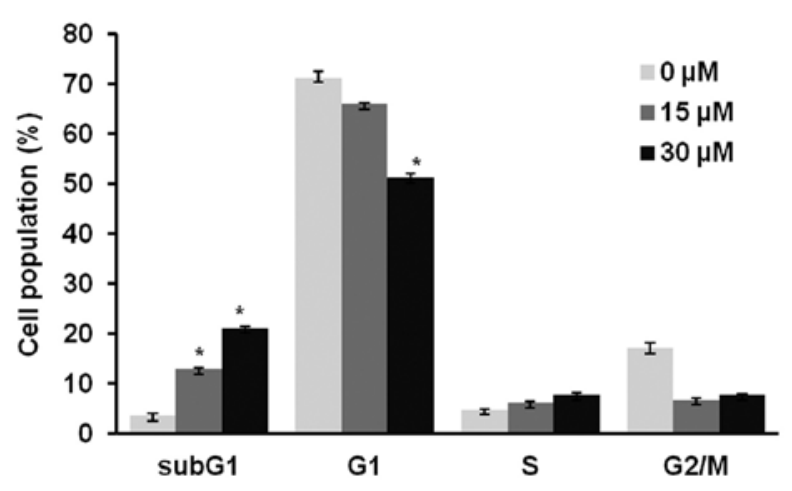

C

$0 \mu \mathrm{M}$
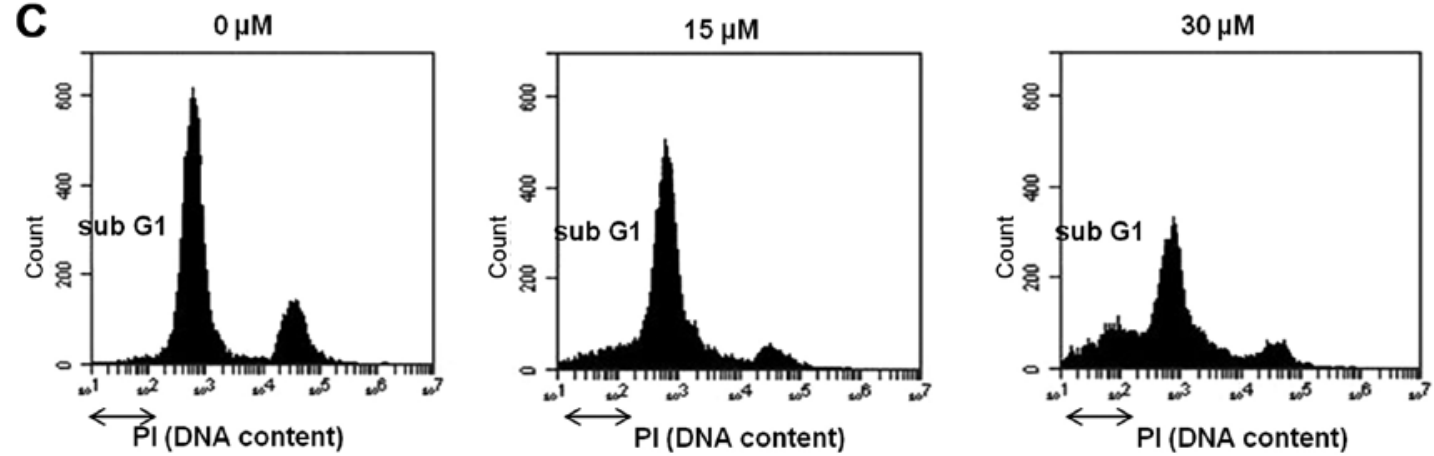

Figure 3. DNA fragmentation and cell cycle distribution of T47D cells treated with $\alpha$-mangostin. (A) DNA fragmentation of T47D cells treated with 0,15 and $30 \mu \mathrm{M} \alpha$-mangostin for $24 \mathrm{~h}$ (M, DNA size marker). (B) The sub G1 peak formed with reduced DNA content represent the presence of apoptotic cells. The two major peaks represent $\mathrm{G} 0 / \mathrm{G} 1$ and $\mathrm{G} 2 / \mathrm{M}$ phases of the cell cycle. Mean apoptotic population of T47D cells was 3.3\% for control cells, while it was increased to 12.6 and $21.0 \%$ after treatment with 15 and $30 \mu \mathrm{M} \alpha$-mangostin for $12 \mathrm{~h}$, respectively. (C) The percentage of cell population in sub G1, G1, S and G2/M phases. Three independent experiments were performed and the results are expressed as mean $\pm \mathrm{SD}$. ${ }^{*} \mathrm{P}<0.05$ compared to the control.

membrane permeability resulting in cytochrome $c$ release to the cytosol. JC-1 staining was used to determine $\Delta \Psi \mathrm{m}$ of T47D cells. At higher membrane potentials or healthy cells, JC-1 forms a complex known as J-aggregates with intense red fluorescence. In contrast, in apoptotic or unhealthy cells with low $\Delta \Psi \mathrm{m}, \mathrm{JC}-1$ remains in the monomeric form with intense green fluorescence. The increased intensity ratio of green to red fluorescence indicated mitochondrial depolarization. The increased green/red ratio was detected in T47D cells treated with $30 \mu \mathrm{M} \alpha$-mangostin for 3,6 and $9 \mathrm{~h}$, while the control cells showed red fluorescence (Fig. 4) indicating that $\alpha$-mangostin induced loss of $\Delta \Psi \mathrm{m}$ in T47D cells.

Effects of $\alpha$-mangostin on the expression of Bcl-2 family proteins and induction of cytochrome c release. The $\mathrm{Bcl}-2$ family is a group of proteins regulating cell survival and cell death. The insertion of Bax into mitochondrial membrane induces the opening of the mitochondrial voltage-dependent anion channel (VDAC). The results showed that $\alpha$-mangostin decreased myeloid cell leukemia (Mcl-1) expression but not B-cell lymphoma-extra large (Bcl-xL) and Bcl-2-associated death promoter (Bad) expression (Fig. 5A). The Bax/Bcl-2 ratio was increased significantly in each $\alpha$-mangostin treated group comparing to the control (Fig. 5B). Bax oligomers increased mitochondrial membrane permeability and cytochrome $c$ release from mitochondria to cytosol in a time-dependent pattern (Fig. 5C).
Effects of $\alpha$-mangostin on caspase-3, caspase-9 and cleaved PARP activation. The expression of active forms of caspases was determined by western blot analysis. As shown in Fig. 5C, cleaved caspase- 3 and cleaved caspase- 9 were induced upon exposure to $\alpha$-mangostin. Thus, $\alpha$-mangostin-induced apoptosis was mediated by caspase- 3 and may be associated with the activation of intrinsic pathway (via caspase-9). In addition, apoptosis induction by $\alpha$-mangostin was accompanied by expression of the apoptosis marker, cleaved PARP (Fig. 5C).

Modulation of MAPK signaling during apoptosis induction by $\alpha$-mangostin. MAPK are important signaling components that control cellular proliferation, differentiation, motility, survival and apoptosis. The results showed that $\alpha$-mangostin induced phosphorylated-p38 expression at $30 \mathrm{~min}$ and the highest level was detected at $2 \mathrm{~h}$. In addition, phosphorylated-JNK1/2 was induced at $15 \mathrm{~min}$ and the highest level was at $6 \mathrm{~h}$. Furthermore, decreased phosphorylated-ERK1/2 at 15 min was detected. Phosphorylated-c-Raf was significantly decreased at 15 and 30 min (Fig. 6A). Once activated, phosphorylated-c-Raf activated the dual specific protein kinases mitogen-activated protein kinase kinase 1 (MEK1) and MEK2, which in turn activated the serine/threonine-specific protein kinase ERK1/2. In summary $\alpha$-mangostin modulated the MAPK(s) pathway resulting in apoptosis induction.

Evaluation of transcription factor and downstream oncogenic products of PI3K/Akt and MAPK. $\alpha$-Mangostin enhanced 

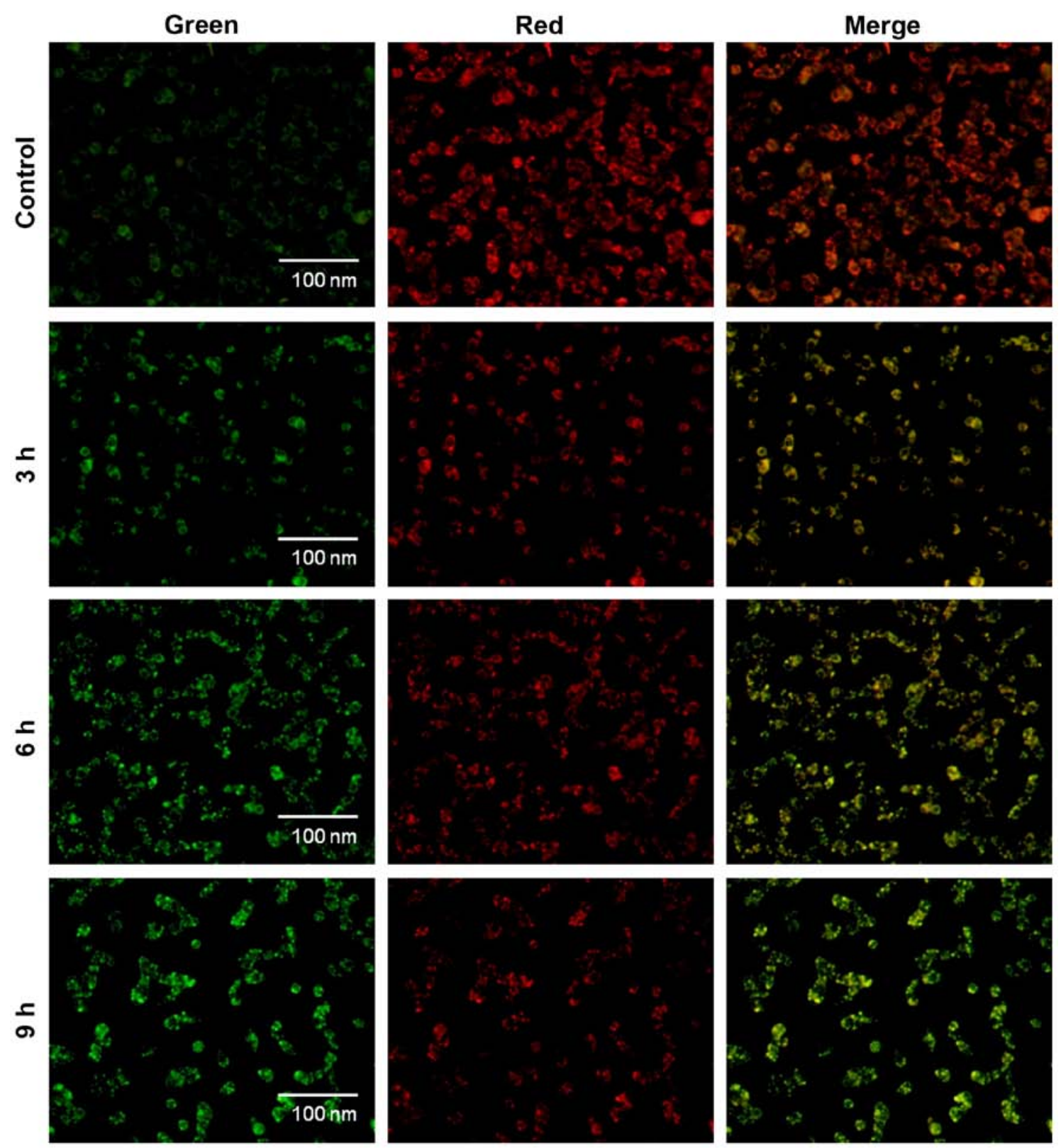

Figure 4. Effect of $\alpha$-mangostin on mitochondrial membrane potential in T47D cells. Cells were treated with $30 \mu \mathrm{M} \alpha$-mangostin for 3,6 and $9 \mathrm{~h}$ and stained with JC-1. The mitochondrial depolarization indicated by an increased green/red fluorescence intensity ratio (magnification, $\mathrm{x} 40$ ).

IкB kinases $\alpha(\mathrm{IKK} \alpha)$ and Src expression whereas decreased nuclear transcription factor kappa B (NF- $\mathrm{B}$ p65) and c-Rel expression (Fig. 6B). This could result in cell proliferation inhibition and inflammation in cancer cells as well as increased sensitivity to antitumor agent and ultimately apoptotic cell death $(48,49)$. Moreover, $\alpha$-mangostin also activated C/EBP homologous protein (CHOP) and c-Jun expression, while suppressed c-Myc expression (Fig. 6B).

$\alpha$-Mangostin inhibits HER2 activation and downstream PI3K/Akt signaling pathway. Activation of the HER2 network results in autophosphorylation of C-terminal tyrosine leading to the recruitment of cytoplasmic signal transducer that regulates cellular processes such as proliferation, apoptosis inhibition and transformation. Therefore, we examined whether $\alpha$-mangostin could activate dephosphorylation of phosphorylated-HER2 (p-HER2). Treatment of T47D cells with $30 \mu \mathrm{M} \alpha$-mangostin resulted in substantially decreased phosphorylated-HER2 Tyr1221/1222 at $30 \mathrm{~min}$ (Fig. 7A), which led to inactivation of RAS/Raf1/MEK/ERK and PI3K/Akt transduction cascade. HER2 stimulates tumor cell growth and renders cellular chemo-resistance involved with the HER2 tyrosine kinase domain.

PI3K/Akt signaling is the major anti-apoptosis pathway that confers survival advantage and drug resistance of cancer cells. Our data clearly indicated the inhibition of PI3K/Akt signaling cascade by $\alpha$-mangostin in T47D cells (Fig. 7B). In addition, Akt phosphorylation at Ser473 and Thr308 was highly suppressed by $\alpha$-mangostin resulting in inhibition of cell proliferation and apoptosis induction.

Effect of $\alpha$-mangostin on inhibition of ER $\alpha$ activation. ER $\alpha$ is a member of NR family transcription factors that is involved 
A
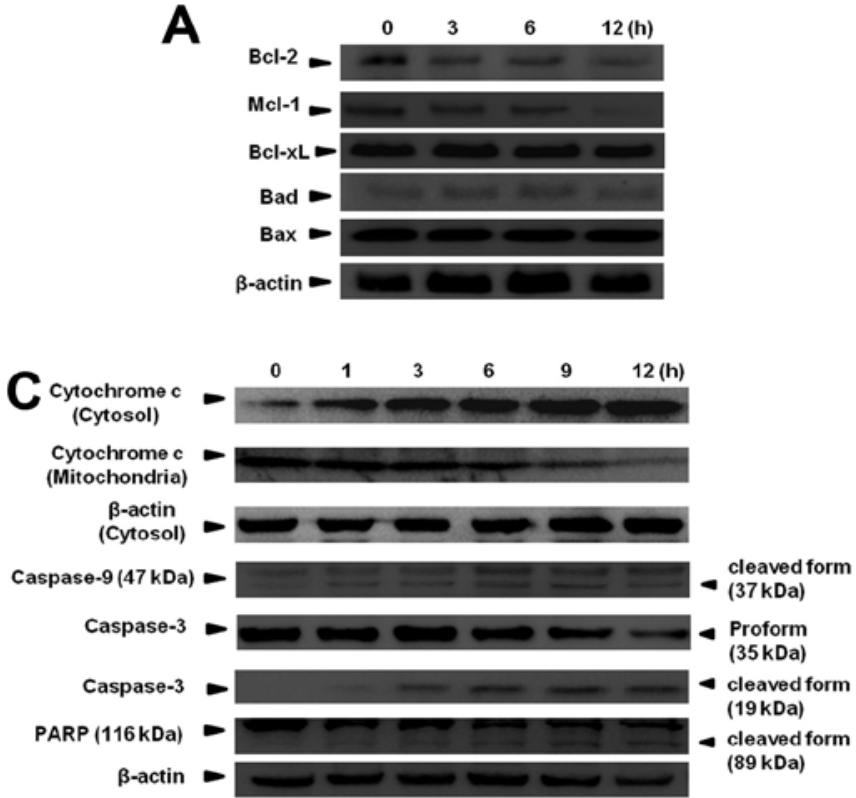
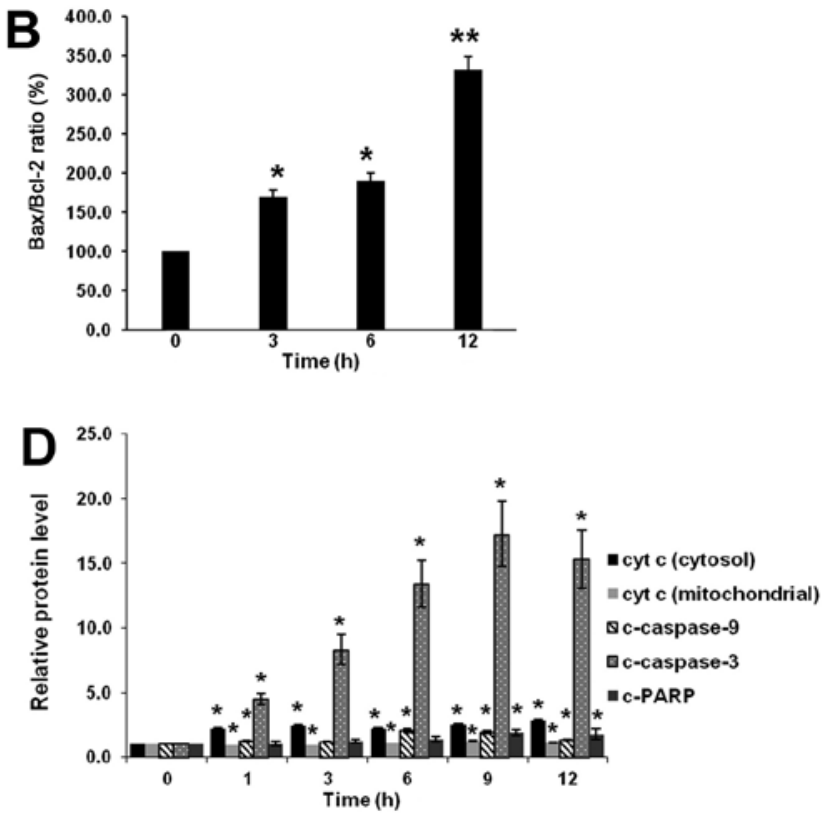

Figure 5. Effect of $\alpha$-mangostin on caspase and Bcl-2 protein family expression in T47D cells. (A) Cells were treated with $30 \mu \mathrm{M} \alpha$-mangostin and the expression of Bcl-2 family protein was examined by western blot analysis. (B) The increased Bax/Bcl-2 ratio upon treatment with $\alpha$-mangostin. (C) Expression of cleaved caspase-3, cleaved caspase-9 and cleaved PARP in T47D cells. Cytochrome $c$ expression was determined both in cytosol and mitochondrial fraction. (D) Relative protein expression of cytochrome $c$, caspase family and cleaved PARP. $\beta$-actin was used as the internal control. The quantitative data are presented as the mean $\pm \mathrm{SD}$ of the percent increase relative to untreated control cells in three independent experiments. Significant values were defined as ${ }^{*} \mathrm{P}<0.05$ and ${ }^{* *} \mathrm{P}<0.01$ as compared to the control.
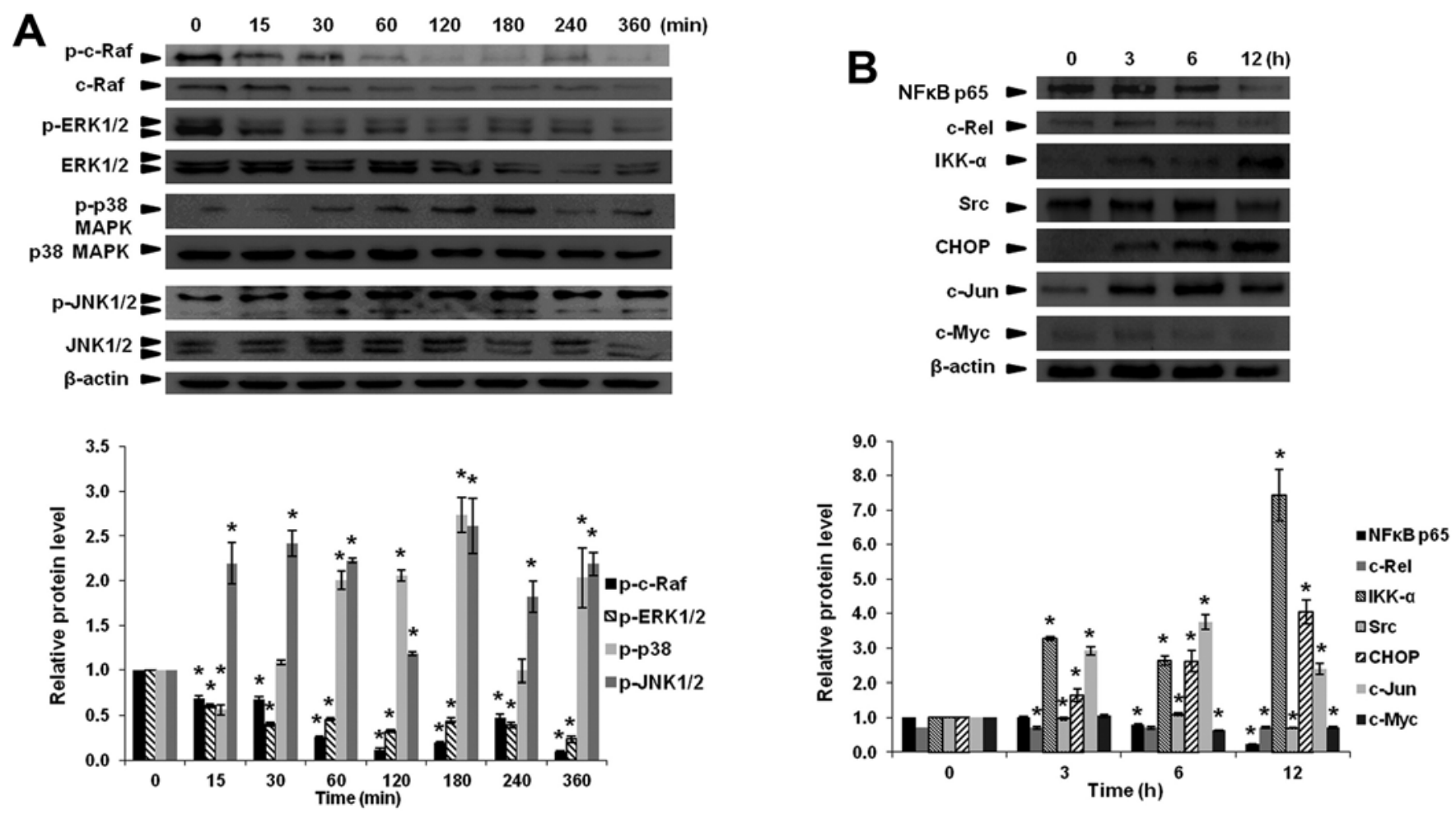

Figure 6. Effect of $\alpha$-mangostin on phosphorylation of c-Raf, MAPK(s) and transcription factors in T47D cells. Cells were treated with $30 \mu \mathrm{M} \alpha-\mathrm{mangostin}$ and examined by western blot analysis. (A) Expression of phosphorylated-c-Raf, phosphorylated-ERK1/2, phosphorylated-p38, phosphorylated-JNK1/2 in T47D cells. (B) Expression of transcription factors downstream of MAPK signaling. $\beta$-actin was used as the internal control. The quantitative data are presented as the mean \pm SD of the percent increase relative to untreated control cells in three independent experiments. Significant values were defined as "P<0.05 as compared to the control.

in cell proliferation and survival. Once activated by estrogen, the $\mathrm{ER} \alpha$ is able to translocate into the nucleus and bind to specific DNA response elements, known as estrogen response elements (EREs), to regulate different gene activities. The 

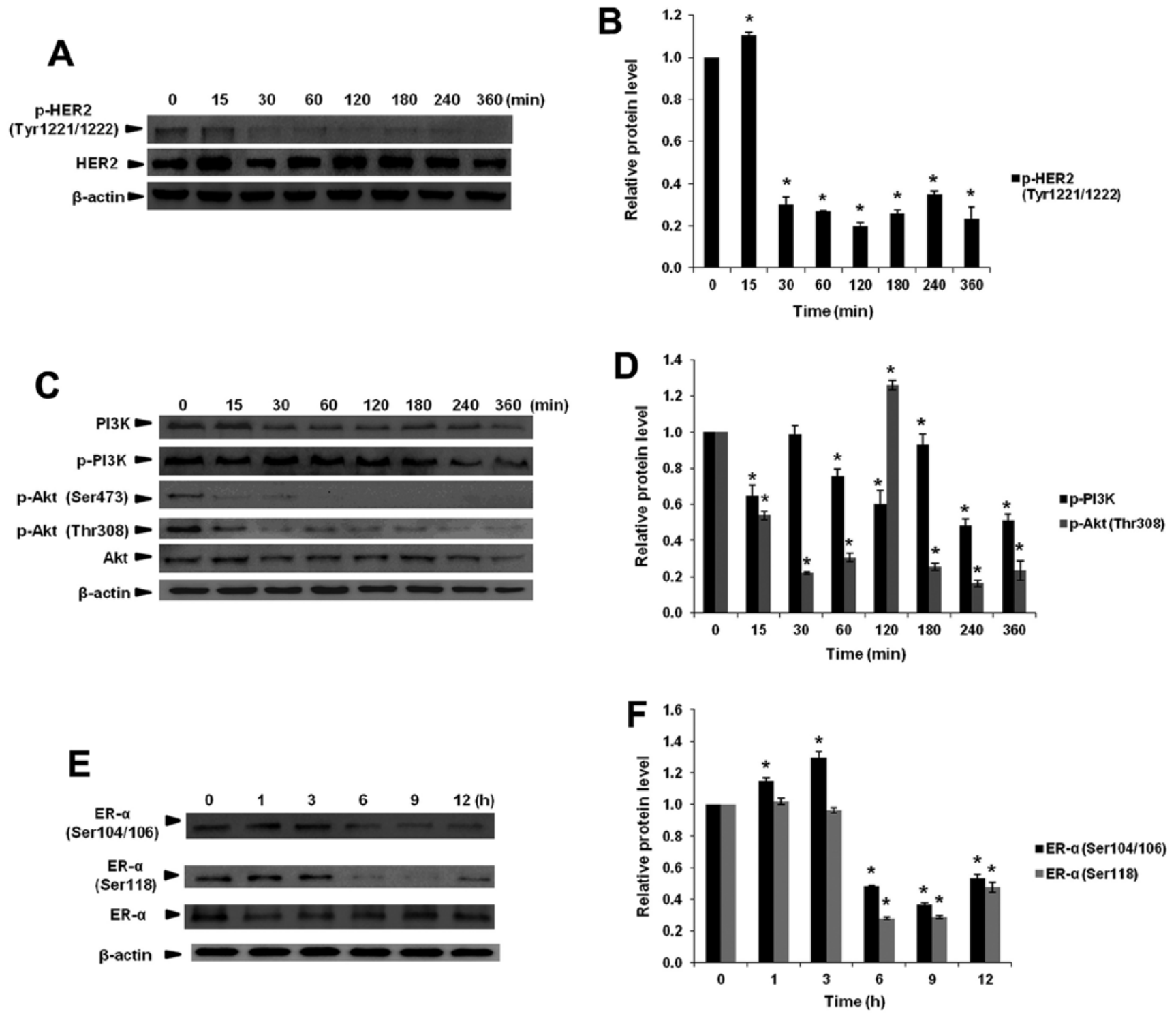

Figure 7. Inhibitory effect of $\alpha$-mangostin on phosphorylation of HER2, PI3K/Akt and ER $\alpha$ signaling molecules in T47D cells upon treatment with $30 \mu \mathrm{M} \alpha$-mangostin by western blot analysis. (A) Expression of total HER2 and phosphorylated-HER2. (B) Relative phosphorylated-HER2 expression. (C) Phosphorylated-PI3K, phosphorylated-Akt at Ser473, Thr308 and total protein expression. (D) Relative phosphorylated-PI3K and phosphorylated-AKT expression. (E) Expression of ER $\alpha$ (Ser104/106) and ER $\alpha$ (Ser118). (F) Relative phosphorylated-ER $\alpha$ expression. $\beta$-actin was used as the internal control. The quantitative data are presented as the mean $\pm \mathrm{SD}$ of the percent increase relative to untreated control cells in three independent experiments. ${ }^{*} \mathrm{P}<0.05$ compared with control.

results showed the decreased phosphorylation of Ser104/106 and Ser118 of ER $\alpha$ upon treatment with $30 \mu \mathrm{M} \alpha$-mangostin at $6 \mathrm{~h}$ (Fig. 7C) implying that $\alpha$-mangostin could inhibit cell proliferation and cell survival through the suppression of ER $\alpha$ phosphorylation in T47D cells.

\section{Discussion and Conclusion}

The goal of the present study was to search for a natural bioactive compound from a plant as anti-breast cancer agent with high specificity to ER and progesterone receptor (PR) positive T47D breast cancer cells. Approximately $75 \%$ of all breast cancers are ER-positive and 65\% are PR-positive cells. Mammary ductal carcinoma is the most common type of breast cancer in women with poor prognosis, resistant to chemotherapy and radiation treatment. Apoptosis-inducing agents are being investigated as a tool for the management of cancer treatment. $\alpha$-Mangostin, one of the xanthones, is the secondary metabolite from mangosteen pericarp possessing various biological activities (35). For this reason, we investigated the potential of $\alpha$-mangostin for human breast carcinoma cell treatment. The results showed that $\alpha$-mangostin could inhibit cell growth in a time- and dose-dependent manner with an $\mathrm{IC}_{50}$ value of $7.5 \pm 0.5 \mu \mathrm{M}$.

The present study showed that $\alpha$-mangostin decreased Mcl-1 expression (Fig. 5A) as well as increased Bax/Bcl-2 ratio (Fig. 5B). The cytosolic cytochrome c level was increased corresponding to the loss of $\Delta \Psi \mathrm{m}$ (Fig. $5 \mathrm{C}$ ). Cytosolic cytochrome $c$ activated procaspase-9 by binding to apoptotic protease activating factor 1 (Apaf1) and activated downstream effector caspase (including caspase-3) then triggered apoptosis induction through the intrinsic pathway. 


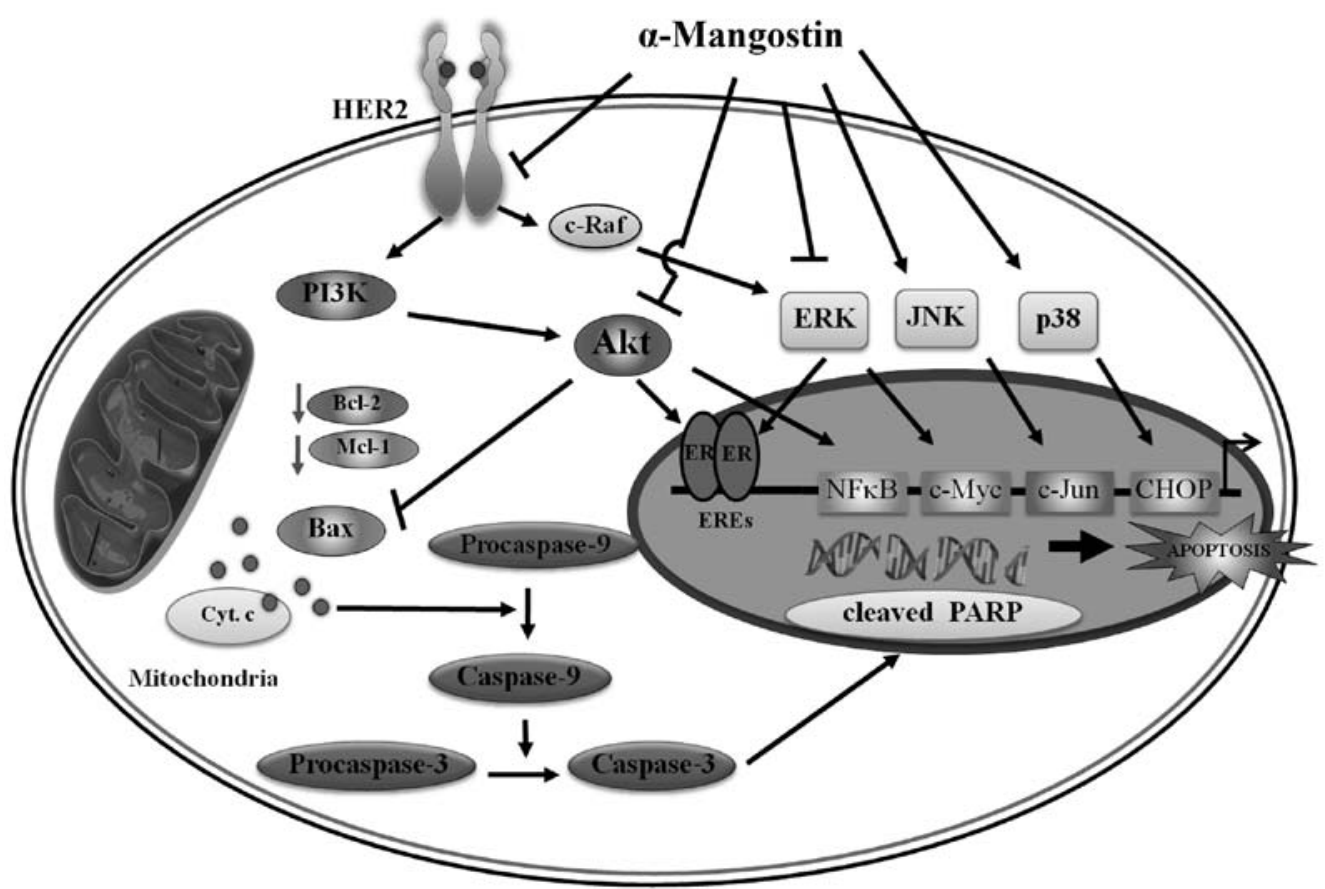

Figure 8. Potential mechanisms of apoptosis induction in T47D human breast cancer cells by $\alpha$-mangostin. Inhibition of ERK1/2 and PI3K/Akt associated with downregulation of phosphorylated-HER2 and ER $\alpha$, which are upstream molecules of survival signaling pathways. $\alpha$-Mangostin induced the activation of p-p38 and p-JNK1/2, promoting apoptosis via modulation of Bcl-2 family proteins leading to cytochrome $c$ release to the cytosol resulting in caspase activation and apoptosis induction of cancer cells.

Our results illustrated that $\alpha$-mangostin modulated MAPK(s) (Fig. 6A) and inactivated ERK1/2 resulting in decreased NF-KBp 65, c-Rel and c-Myc but increased IKK $\alpha$ expression, whereas, activation of $\mathrm{p} 38$ and JNK1/2 led to CHOP and c-Jun expression, respectively. A limitation of the study at the present stage, is that further experiments with inhibitors are required. There are many related studies including phosphorylation of c-Jun leading to activator protein 1 (AP-1) formation which involved pro-apoptotic protein transcription and apoptosis induction (50). The JNK1/2 played a key role in CHOP induction and cell death by ER stress in rat hepatocytes (51). Moreover, $\mathrm{CHOP} /$ death receptor 5 (DR5) upregulation was mediated via JNK1/2 phosphorylation in $\alpha$-TEA induced apoptosis in MDA-MB-231 and MCF-7 cells (52). Our results showed rapid cell growth inhibition and apoptosis induction in T47D cells by $\alpha$-mangostin at $15 \mathrm{~min}$. $\alpha$-Mangostin also decreased p-HER2 at Tyr1221/1222 as compared with proform-HER2 expression (Fig. 7A) leading to downregulation of Ras-Raf-MAP kinase and PI3K/Akt transduction pathways (53). PI3K/Akt signaling pathway is essential for cell survival and the expression of a constitutively active PI3K/Akt pathway induces multidrug resistance and prevents apoptosis in a variety of cell types. Our results showed that $\alpha$-mangostin could decrease the phosphorylation of PI3K and Akt at Ser473 and Thr308 (Fig. 7B). Interestingly, we found that p-Akt at both sites were decreased significantly suggesting that Akt may be a target of $\alpha$-mangostin in breast cancer. Previous studies showed that inhibition of the PI3K/Akt pathway with doxorubicin, trastuzumab, etoposide, tamoxifen increased apoptosis induction implying that measuring Akt activity would directly be beneficial to breast cancer patients $(54,55)$. Thus, our results implied that inhibition of the PI3K/Akt pathway by $\alpha$-mangostin may be of great benefit when combining with traditional cytotoxic chemotherapy, immune therapy and endocrine based therapy.

In addition, estrogen is also involved in normal breast development as well as in breast cancer growth and progression. The biological actions of estrogen are mediated by binding to nuclear ER $\alpha$ and ER $\alpha$. Treatment with ER antagonists is the current hormone therapy of choice for ER $\alpha$-positive breast cancer treatment. In the present study, we found that $\alpha$-mangostin could inhibit ER $\alpha$ phosphorylation in T47D cells at $6 \mathrm{~h}$.

In conclusion, $\alpha$-mangostin inhibited cell proliferation and induced apoptosis associated with HER2/PI3K/Akt and MAPK signaling pathway in human breast carcinoma T47D cells (Fig. 8). Therefore, $\alpha$-mangostin may provide anticancer action in clinical application in human breast cancer treatment.

\section{Acknowledgements}

We would like to thank the Royal Golden Jubilee Ph.D. Program, Thailand Research Fund (grant no. PHD/0312/2550), the Strategic Wisdom and Research Institute, Srinakharinwirot University and the Research Division, Faculty of Medicine, Srinakharinwirot University. We would also like thank Dr Aungkana Krajarng for her help in $\alpha$-mangostin preparation.

\section{References}

1. Osborne CK, Shou J, Massarweh S and Schiff R: Crosstalk between estrogen receptor and growth factor receptor pathways as a cause for endocrine therapy resistance in breast cancer. Clin Cancer Res 11: 865s-870s, 2005.

2. Parton M, Dowsett M and Smith I: Studies of apoptosis in breast cancer. BMJ 322: 1528-1532, 2001. 
3. Hanstein B, Djahansouzi S, Dall P, Beckmann MW and Bender HG: Insights into the molecular biology of the estrogen receptor define novel therapeutic targets for breast cancer. Eur J Endocrinol 150: 243-255, 2004.

4. Yarden Y: Biology of HER2 and its importance in breast cancer. Oncology 61 (Suppl 2): 1-13, 2001.

5. Yamamoto T, Ikawa S, Akiyama T, Semba K, Nomura N, Miyajima N, Saito T and Toyoshima K: Similarity of protein encoded by the human c-erb-B-2 gene to epidermal growth factor receptor. Nature 319: 230-234, 1986.

6. Hynes NE and Stern DF: The biology of erbB-2/neu/HER-2 and its role in cancer. Biochim Biophys Acta 1198: 165-184, 1994.

7. Arpino G, Wiechmann L, Osborne CK and Schiff R: Crosstalk between the estrogen receptor and the HER tyrosine kinase receptor family: Molecular mechanism and clinical implications for endocrine therapy resistance. Endocr Rev 29: 217-233, 2008.

8. Baselga J: Treatment of HER2-overexpressing breast cancer. Ann Oncol 21 (Suppl 7): vii36-vii40, 2010.

9. Kim KC, Kim JS, Son JK and Kim IG: Enhanced induction of mitochondrial damage and apoptosis in human leukemia HL-60 cells by the Ganoderma lucidum and Duchesnea chrysantha extracts. Cancer Lett 246: 210-217, 2007.

10. Mow BM, Blajeski AL, Chandra J and Kaufmann SH: Apoptosis and the response to anticancer therapy. Curr Opin Oncol 13: 453-462, 2001

11. Kim R: Recent advances in understanding the cell death pathways activated by anticancer therapy. Cancer 103: 1551-1560, 2005.

12. Mellier G, Huang S, Shenoy K and Pervaiz S: TRAILing death in cancer. Mol Aspects Med 31: 93-112, 2010.

13. Chipuk JE, Moldoveanu T, Llambi F, Parsons MJ and Green DR: The BCL-2 family reunion. Mol Cell 37: 299-310, 2010.

14. Li D, Qu X, Hou K, Zhang Y, Dong Q, Teng Y, Zhang J and Liu Y: PI3K/Akt is involved in bufalin-induced apoptosis in gastric cancer cells. Anticancer Drugs 20: 59-64, 2009.

15. Takeuchi H, Kim J, Fujimoto A, Umetani N, Mori T, Bilchik A, Turner R, Tran A, Kuo C and Hoon DS: X-Linked inhibitor of apoptosis protein expression level in colorectal cancer is regulated by hepatocyte growth factor/C-met pathway via Akt signaling. Clin Cancer Res 11: 7621-7628, 2005.

16. Lee SM, Lee CT, Kim YW, Han SK, Shim YS and Yoo CG: Hypoxia confers protection against apoptosis via PI3K/Akt and ERK pathways in lung cancer cells. Cancer Lett 242: 231-238, 2006.

17. Bak Y, Kim H, Kang JW, Lee DH, Kim MS, Park YS, Kim JH, Jung KY, Lim Y, Hong J, et al: A synthetic naringenin derivative, 5-hydroxy-7,4'-diacetyloxyflavanone-N-phenyl hydrazone (N101-43), induces apoptosis through up-regulation of Fas/ FasL expression and inhibition of PI3K/Akt signaling pathways in non-small-cell lung cancer cells. J Agric Food Chem 59: 10286-10297, 2011.

18. Xia Z, Dickens M, Raingeaud J, Davis RJ and Greenberg ME: Opposing effects of ERK and JNK-p38 MAP kinases on apoptosis. Science 270: 1326-1331, 1995.

19. Sebolt-Leopold JS: Development of anticancer drugs targeting the MAP kinase pathway. Oncogene 19: 6594-6599, 2000.

20. Hilger RA, Scheulen ME and Strumberg D: The Ras-RafMEK-ERK pathway in the treatment of cancer. Onkologie 25: 511-518, 2002 .

21. Yager JD and Davidson NE: Estrogen carcinogenesis in breast cancer. N Engl J Med 354: 270-282, 2006.

22. de Leeuw R, Neefjes J and Michalides R: A role for estrogen receptor phosphorylation in the resistance to tamoxifen. Int $J$ Breast Cancer 2011: 232435, 2011.

23. Thomas RS, Sarwar N, Phoenix F, Coombes RC and Ali S: Phosphorylation at serines 104 and 106 by Erk1/2 MAPK is important for estrogen receptor-alpha activity. J Mol Endocrinol 40: $173-184,2008$

24. Weitsman GE, Li L, Skliris GP, Davie JR, Ung K, Niu Y, Curtis-Snell L, Tomes L, Watson PH and Murphy LC: Estrogen receptor-alpha phosphorylated at Ser118 is present at the promoters of estrogen-regulated genes and is not altered due to HER-2 overexpression. Cancer Res 66: 10162-10170, 2006.

25. Bhatt S, Xiao Z, Meng Z and Katzenellenbogen BS: Phosphorylation by $\mathrm{p} 38$ mitogen-activated protein kinase promotes estrogen receptor $\alpha$ turnover and functional activity via the SCF(Skp2) proteasomal complex. Mol Cell Biol 32: 1928-1943, 2012
26. Marino M, Acconcia F, Bresciani F, Weisz A, Trentalance A and Trentalance A: Distinct nongenomic signal transduction pathways controlled by 17beta-estradiol regulate DNA synthesis and cyclin $\mathrm{D}(1)$ gene transcription in HepG2 cells. Mol Biol Cell 13: 3720-3729, 2002

27. Marino M, Acconcia F and Trentalance A: Biphasic estradiolinduced AKT phosphorylation is modulated by PTEN via MAP kinase in HepG2 cells. Mol Biol Cell 14: 2583-2591, 2003.

28. Gutierrez-Orozco F and Failla ML: Biological activities and bioavailability of mangosteen xanthones: A critical review of the current evidence. Nutrients 5: 3163-3183, 2013.

29. Sakagami Y, Iinuma M, Piyasena KG and Dharmaratne HR: Antibacterial activity of alpha-mangostin against vancomycin resistant Enterococci (VRE) and synergism with antibiotics. Phytomedicine 12: 203-208, 2005.

30. Gopalakrishnan G, Banumathi B and Suresh G: Evaluation of the antifungal activity of natural xanthones from Garcinia mangostana and their synthetic derivatives. J Nat Prod 60: 519-524, 1997.

31. Sidahmed HM, Abdelwahab SI, Mohan S, Abdulla MA, Taha MME, Hashim NM, Hadi AHA, Vadivelu J, Fai ML, Rahmani M, et al: alpha-Mangostin from Cratoxylum arborescens (Vahl) blume demonstrates anti-ulcerogenic property: A mechanistic study. Evid Based Complement Alternat Med 2013: 450840, 2013.

32. Huang HJ, Chen WL, Hsieh RH and Hsieh-Li HM: Multifunctional effects of mangosteen pericarp on cognition in C57BL/6J and triple transgenic Alzheimer's mice. Evid Based Complement Alternat Med 2014: 813672, 2014.

33. Pedraza-Chaverrí J, Reyes-Fermín LM, Nolasco-Amaya EG, Orozco-Ibarra M, Medina-Campos ON, GonzálezCuahutencos O, Rivero-Cruz I and Mata R: ROS scavenging capacity and neuroprotective effect of alpha-mangostin against 3-nitropropionic acid in cerebellar granule neurons. Exp Toxicol Pathol 61: 491-501, 2009.

34. Pedraza-Chaverri J, Cárdenas-Rodríguez N, Orozco-Ibarra M and Pérez-Rojas JM: Medicinal properties of mangosteen (Garcinia mangostana). Food Chem Toxicol 46: 3227-3239, 2008.

35. Devi Sampath P and Vijayaraghavan K: Cardioprotective effect of alpha-mangostin, a xanthone derivative from mangosteen on tissue defense system against isoproterenol-induced myocardial infarction in rats. J Biochem Mol Toxicol 21: 336-339, 2007.

36. Suksamrarn S, Suwannapoch N, Phakhodee W, Thanuhiranlert J, RatananukulP, Chimnoi Nand Suksamrarn A: Antimycobacterial activity of prenylated xanthones from the fruits of Garcinia mangostana. Chem Pharm Bull (Tokyo) 51: 857-859, 2003.

37. Nguyen PT and Marquis RE: Antimicrobial actions of $\alpha$-mangostin against oral streptococci. Can J Microbiol 57: 217-225, 2011.

38. Kaomongkolgit R, Jamdee K and Chaisomboon N: Antifungal activity of alpha-mangostin against Candida albicans. J Oral Sci 51: 401-406, 2009

39. Chen LG, Yang LL and Wang CC: Anti-inflammatory activity of mangostins from Garcinia mangostana. Food Chem Toxicol 46: 688-693, 2008.

40. Chairungsrilerd N, Furukawa K, Ohta T, Nozoe S and Ohizumi Y: Pharmacological properties of alpha-mangostin, a novel histamine H1 receptor antagonist. Eur J Pharmacol 314: 351-356, 1996.

41. Sánchez-Pérez Y, Morales-Bárcenas R, García-Cuellar CM, López-Marure R, Calderon-Oliver M, Pedraza-Chaverri J and Chirino YI: The alpha-mangostin prevention on cisplatin-induced apoptotic death in LLC-PK1 cells is associated to an inhibition of ROS production and $\mathrm{p} 53$ induction. Chem Biol Interact 188: 144-150, 2010.

42. Nabandith V, Suzui M, Morioka T, Kaneshiro T, Kinjo T, Matsumoto K, Akao Y, Iinuma M and Yoshimi N: Inhibitory effects of crude alpha-mangostin, a xanthone derivative, on two different categories of colon preneoplastic lesions induced by 1, 2-dimethylhydrazine in the rat. Asian Pac J Cancer Prev 5: 433-438, 2004

43. Nakagawa $Y$, Iinuma $M$, Naoe $T$, Nozawa $Y$ and Akao $Y$ : Characterized mechanism of alpha-mangostin-induced cell death: Caspase-independent apoptosis with release of endonuclease-G from mitochondria and increased miR-143 expression in human colorectal cancer DLD-1 cells. Bioorg Med Chem 15: $5620-5628,2007$. 
44. Matsumoto K, Akao Y, Yi H, Ohguchi K, Ito T, Tanaka T, Kobayashi E, Iinuma M and Nozawa Y: Preferential target is mitochondria in alpha-mangostin-induced apoptosis in human leukemia HL60 cells. Bioorg Med Chem 12: 5799-5806, 2004.

45. Krajarng A, Nakamura Y, Suksamrarn S and Watanapokasin R: $\alpha$-Mangostin induces apoptosis in human chondrosarcoma cells through downregulation of ERK/JNK and Akt signaling pathway. J Agric Food Chem 59: 5746-5754, 2011.

46. Tewtrakul S, Wattanapiromsakul C and Mahabusarakam W: Effects of compounds from Garcinia mangostana on inflammatory mediators in RAW264.7 macrophage cells. J Ethnopharmacol 121: 379-382, 2009.

47. Sebastian KS and Thampan RV: Differential effects of soybean and fenugreek extracts on the growth of MCF-7 cells. Chem Biol Interact 170: 135-143, 2007.

48. Sethi G, Sung B and Aggarwal BB: Nuclear factor-kappaB activation: From bench to bedside. Exp Biol Med (Maywood) 233: 21-31, 2008.

49. Tabas I and Ron D: Integrating the mechanisms of apoptosis induced by endoplasmic reticulum stress. Nat Cell Biol 13: 184-190, 2011.
50. Dhanasekaran DN and Reddy EP: JNK signaling in apoptosis Oncogene 27: 6245-6251, 2008.

51. Li J and Holbrook NJ: Elevated gadd153/chop expression and enhanced c-Jun $\mathrm{N}$-terminal protein kinase activation sensitizes aged cells to ER stress. Exp Gerontol 39: 735-744, 2004.

52. Tiwary R, Yu W, Li J, Park SK, Sanders BG and Kline K: Role of endoplasmic reticulum stress in alpha-TEA mediated TRAIL/ DR5 death receptor dependent apoptosis. PLoS One 5: e11865, 2010.

53. Ménard S, Tagliabue E, Campiglio M and Pupa SM: Role of HER2 gene overexpression in breast carcinoma. J Cell Physiol 182: $150-162,2000$.

54. Clark AS, West K, Streicher S and Dennis PA: Constitutive and inducible Akt activity promotes resistance to chemotherapy, trastuzumab, or tamoxifen in breast cancer cells. Mol Cancer Ther 1: 707-717, 2002.

55. Brognard J, Clark AS, Ni Y and Dennis PA: Akt/protein kinase $\mathrm{B}$ is constitutively active in non-small cell lung cancer cells and promotes cellular survival and resistance to chemotherapy and radiation. Cancer Res 61: 3986-3997, 2001. 